\title{
Research on the Construction of Socialist Core Values of College Students in the New Era under the Background of WeChat
}

\author{
Minghui Wang \\ Chang Chun University of Technology, Changchun, China \\ wmh@ccut.edu.cn
}

Keywords: WeChat, college student, core values, structure.

\begin{abstract}
As a typical representative of WeChat since the media age, in the introduction of several years has been widely used for young people, into the people's life, for the contemporary college students, many new features WeChat use to strengthen the peer group influence, to a certain extent affected the core values of the university education validity and authority, and need workers because of the situation the ideological and political education, enhance the ability to use WeChat innovation, the core values of education, education and establish a linkage mechanism for online guide line, promote the socialist core values of contemporary college students education effect.
\end{abstract}

\section{Introduction}

The history of the development of human society indicates that the most lasting and deepest force for a nation or a nation is the core values approved by the whole society. The core values, carrying a nation, a country's spiritual pursuit, embodies the values of a society to judge the right and wrong.

For the college students in the new era, the value orientation of youth determines the value orientation of the whole society in the future, and youth is in the period of formation and establishment of values. It is very important to grasp the values in this period. Faced with the surging of all kinds of thoughts in the information age, especially after entering the era of self media represented by WeChat products, the value orientation of pluralism has a certain impact on the construction of College Students' values in the new era.

\section{The Influence of WeChat on the Core Values of College Students in the New Era}

A typical representative of WeChat software as the Internet era from the media, popular contemporary college students favor in the channels of information dissemination from the media trend, information tends to immediately, fragmentation, to the center, affected by the cultivation of inevitable socialist core values of College students.

\subsection{Strengthening the Value Influence of Contemporary College Students' Peer Group.}

In the core values education of college students, the influence of peer group usually surpasses the influence of teachers and parents. Peer group is more profound and long-term. In the book "culture and commitment", Meade believes that "the influence of the peer group in the modern society is enough to change the way of the transmission of traditional culture". Wu Zhiyan, an empirical study of contemporary college students in China, finds that there is a strong correlation between contemporary college students' occupational values, interpersonal values and spouse values.

WeChat strengthened the peer group influence because of the values of contemporary college students from the media age peer group social network breaks the space constraints, WeChat in this virtual space on the use of mobile phone communication of the original resource record, QQ friends, classmates, friends and other peers will be integrated into WeChat group of friends. In support of WeChat pictures, voice, group chat and other communication channels on the college students' appeal most, $85 \%$ of students believe that compared to a single traditional text communication, voice, pictures, video and other integrated communication makes WeChat friends exchanges more interesting, cordial, enhance exchanges between the same generation group frequency, the frequency of communication in contemporary students through the WeChat communication and peer group has 
exceeded the frequency with parents, teachers, and strengthen the value of the WeChat platform for peer group influence view.

\subsection{Reducing the Validity of the Cultivation of College Students' Core Values.}

The validity of contemporary college students' core values cultivation is the degree of effectiveness achieved in the core value education process, reflecting the college students' recognition of contemporary socialist core values and their internalization ability in action. Students from the media through the channels of the WeChat era of massive information, the information content is complex, many information released at random, not through the judgment of authenticity, many viewpoints on the WeChat platform together, the formation and establishment of college students have an adverse impact on the values in the lead, values deviation, even in bad values through the WeChat channel communication the formation of "vulgar" and "utilitarian" and "Westernization" wrong orientation, which increased the burden of the cultivation of correct values of college students in a certain extent.

Specifically, in the economy, the market economy negative impact on WeChat has been expanded, pragmatism, hedonism, money worship and other bad values through the packaging, publicity is often subject to differential ability of college students, the blind pursuit of decadent luxury lifestyle, with WeChat in popular share the success as patients frequently spread overnight case, which is behind the distorted view of the success, happiness, success of WeChat if things go on like this by the students is tending to be quick. In politics, wanton propaganda on the contemporary social problems of the WeChat platform, false reports from the media release message, attracted the attention of contemporary college students, young people even aroused resentment against the government, dissatisfaction with the reform of the college students experience is not deep, easy anti reform and concept of socialist core the value of anti socialist ideology under the guidance of the various understanding of the cause of cognitive dissonance.

\subsection{WeChat's Spread of Multi Centralization Weakens the Authority of College Students' Core Values.}

The traditional core values education of college students is generally in a formal theory of classroom based teaching, through lectures, meetings, lectures and other forms of theme, on College Students' socialist core values education and guided by ideological and political education, characteristics of this kind of education is a one-way communication, teaching, high strength communication, and in the process of education, the ideological and political education people tend to grasp the information and voice control absolute, single center core values of education as the right to information and the right to speak, the traditional mode of education of contemporary college students are passive.

After the emergence of the self media represented by WeChat, the core values education classroom is a single center of teachers, and the closed education mode has been broken. Everybody has a smart mobile phone of the college students are no longer passive recipients of information, to use WeChat to become the maker of information and communication, so everyone from the media to become the center of information, access to information, information transmission speed has been rapidly increasing fission, traditional education workers have the information has been unable to meet college students' needs, the authority also gradually lose, coupled with the new generation of young college students' personality, active thinking, strong reverse psychology, easy to believe in the information dissemination of peer group WeChat, the center of University Ideological and political teacher status and authority of the threat, the cultivation of College Students' core value authority is weakened.

\section{The Construction Strategy of the Core Values of College Students in the WeChat Era}

\subsection{Promoting the Use of New Media for Ideological and Political Educators and Guiding Subculture.}

The degree of use and mastery of WeChat by ideological and political educators is obviously less than that of contemporary college students. The older ideological and political educators didn't open 
WeChat or lack smart phones, and could not keep pace with the development of students' values in information receiving. It is necessary for colleges and universities to enhance the training of new media use ability for ideological and political educators, so that university teachers can fully understand the characteristics of WeChat and adapt to the education of socialist core values under the new situation.

At present, the phenomenon of subculture appears in WeChat's virtual space. WeChat users form special "fields" on the Internet, and build a sub culture circle dominated by network values. At present our country is in the period of social transformation, the old and new contradictions interweave, superposition of short-term difficulties and long-term problems, the reform into the deep water area to tackle tough, quickly spread to many social problems in the mobile Internet, from the media between the emergence of different values, different cultures of various thoughts collision, interaction. Due to the lack of rich social experience and deep insight ability to social problems, contemporary college students are confused by the idea of diversified values under the influence of Internet subculture, and are easily led by irrational ideas and go astray. The ideological and political education need to fully understand the status of college students in their use of WeChat, to WeChat, WeChat through the media to establish education of their own influence, to guide students to a correct view of the transformation of social problems, the development of college students with the history, the eye understanding of the current society, the formation of rational values.

\subsection{Establishing the Campus WeChat Platform and Innovating the Core Values Education Mode.}

With the progress of social science and technology and the change of ideology and ideas of college students, the education of core values should keep pace with the times and change in time. This requires ideological educators to actively innovate the way of core values education, seize the opportunity of education in the tide of mobile Internet, and establish the network position of core values education. The WeChat public platform of common concern to establish the school students, campus, campus style show called transfer. The Youth League Committee of the Changchun University of Technology WeChat public platform as an example, the students' daily to push the campus information, good deeds, perception of philosophy, micro remind, lost and so on, to study life of contemporary college students, help students establish a correct concept of core value in learning and sharing.

\subsection{Using a Variety of Communication Methods of WeChat to Establish the Linkage Mechanism of Online Guidance and Offline Education.}

Make full use of WeChat's LBS, voice dialogue, picture video transmission and other functional advantages to form the core values of the online diversification of information communication. Educators should design some students discussion topics of common concern, invited teachers, alumni, community leaders, and college students to set up the opening of WeChat interactive, with examples and deeds of the students around the core values of education, with examples of education students around the students, guide the students with students' language, and help them to establish a sense of pride and sense of responsibility. At the same time, under line education can not be ignored, WeChat as a virtual space can not completely replace the actual education between teachers and students under the line. In the use of WeChat and other new media technology to carry out the core values of education, must pay attention to face-to-face emotional exchange with the students in the network, strengthen the humane care and psychological counseling, the organic combination of adhering to the "virtual" and "reality", the formation of the line of force, enhance the contemporary college students' Socialist Core Values Education effect.

\section{References}

[1]. Xi Jinping. Young people should conscientiously practice the core values of socialism [N]. Chinese Communist Party News Network. 
[2]. Yi Mu. WeChat active user 438 million, the first approaching rival WhatsApp [N]. The Great Wall network.

[3]. Mead. Culture and commitment [M]. Shijiazhuang: Hebei people's publishing house. 